\title{
A STUDY OF RHEUMATIC DISEASE IN A CANADIAN INDIAN POPULATION* \\ II. RHEUMATOID ARTHRITIS IN THE HAIDA INDIANS \\ BY
}

\author{
J. P. GOFTON, H. S. ROBINSON, AND G. E. PRICE \\ Canadian Arthritis and Rheumatism Society, Vancouver, B.C.
}

In the first part of this study (Robinson, Gofton, and Price, 1963), we described a survey of the Haida Indians of the Queen Charlotte Islands, British Columbia, and reported an unexpectedly high prevalence of Marie-Strümpell spondylitis. In the present communication the full data on rheumatoid arthritis are now presented.

The results of this survey are set forth in two sections:

(A) A comparison with the Wensleydale-Leigh (W.-L.) study of Lawrence (1961), using the A.R.A. 1958 diagnostic criteria (Ropes, Bennett, Cobb, Jacox, and Jessar, 1959)

(B) An evaluation of disease prevalence by the A.R.A. 1962 criteria (Kellgren, 1962) for active and inactive rheumatoid arthritis, and other data of interest.

Note.-The A.R.A. criteria of 1958 for the diagnosis of rheumatoid arthritis do not exclude cases of Marie Strümpell spondylitis. Clinical, radiological, and serological data are included in the summation of criteria even if the respondent is known to have Marie Strümpell spondylitis. Tables I and IV therefore include data on cases of Marie Strümpell spondylitis.

The A.R.A. criteria of 1962 specifically exclude data on Marie Strümpell spondylitis. The respondents are included in the population total, but positive features on definite cases are excluded from Tables II and III.

* Through the assistance of Federal Health Grant No. 609-7-48 and the Canadian Arthritis and Rheumatism Society, B.C. Division.
(A) 1958 Criteria-(Ropes and others, 1959)

(1) Serological.-The sheep cell agglutination test (SCAT) of Ball (1950) was used in both the Haida and W.-L. studies. All tests were conducted in Ball's laboratory on frozen sera.

(2) Radiological.-From an initial comparison of readings in an exchange of films, it was apparent that Lawrence's interpretations in the W.-L. study (1961) were more "sensitive" than ours. With the generous cooperation of Lawrence, we were able to obtain his interpretation and grading of our Haida films. These we applied directly to the score of criteria for each respondent and recalculated the totals. This resolved the differences in interpretation between Lawrence and the authors, although it may involve secular changes in grading in Lawrence's readings of the two sets of films.

Cervical spine findings were excluded in both studies.

(3) Clinical.-All clinical gradings are those of the Vancouver observers.

The following notations are used; see Table I (opposite):

HV.-Vancouver clinical grading; Vancouver $x$-ray interpretation; SCAT.

HL.-Vancouver clinical grading; Lawrence $x$-ray interpretation; SCAT.

W.-L.L-Lawrence clinical grading; Lawrence $x$-ray interpretation; SCAT.

For comparison of disease prevalence in the Haidas and the W.-L.L respondents, the notation HL is compared to W.-L.L.

The two populations (HL and W.-L.L) may be compared as follows:

\begin{tabular}{|c|c|c|c|c|}
\hline \multirow{2}{*}{$\operatorname{Sex}$} & \multirow{2}{*}{ Comparisons } & \multicolumn{2}{|c|}{ Point Prevalence (per cent.) } & \multirow{2}{*}{ Significance } \\
\hline & & HL & W.-L.L. & \\
\hline Female & $\begin{array}{l}\text { Definite disease not significantly different } \\
\text { Probable disease more prevalent in W.-L.L } \\
\text { SCAT positives not significantly different } \\
\text { Erosive disease not significantly different } \\
\quad \text { (Lawrence's interpretation) }\end{array}$ & $\begin{array}{l}1 \cdot 0 \\
1 \cdot 0 \\
3 \cdot 5 \\
3 \cdot 5\end{array}$ & $\begin{array}{l}1 \cdot 6 \\
4 \cdot 4 \\
5 \cdot 0 \\
8 \cdot 0\end{array}$ & $\begin{array}{l}\text { Not significant } \\
P=0.05 \\
\text { Not significant } \\
\text { Not significant } \\
(0 \cdot 1>P>0 \cdot 05)\end{array}$ \\
\hline Male & $\begin{array}{l}\text { Definite disease not significantly different } \\
\text { Probable disease not significantly different } \\
\text { SCAT positives not significantly different } \\
\text { Erosive disease not significantly different } \\
\quad \text { (Lawrence's interpretation) }\end{array}$ & $\begin{array}{l}0 \cdot 4 \\
1 \cdot 7 \\
1 \cdot 2 \\
9 \cdot 2\end{array}$ & $\begin{array}{l}0 \cdot 5 \\
2 \cdot 0 \\
4 \cdot 0 \\
8 \cdot 0\end{array}$ & $\begin{array}{l}\text { Not significant } \\
\text { Not significant } \\
\text { Not significant } \\
\text { Not significant }\end{array}$ \\
\hline
\end{tabular}


TABLE I

AMERICAN RHEUMATISM ASSOCIATION CRITERIA APPLIED TO THE

HAIDA INDIAN POPULATION

(after Lawrence, 1961, Table I)

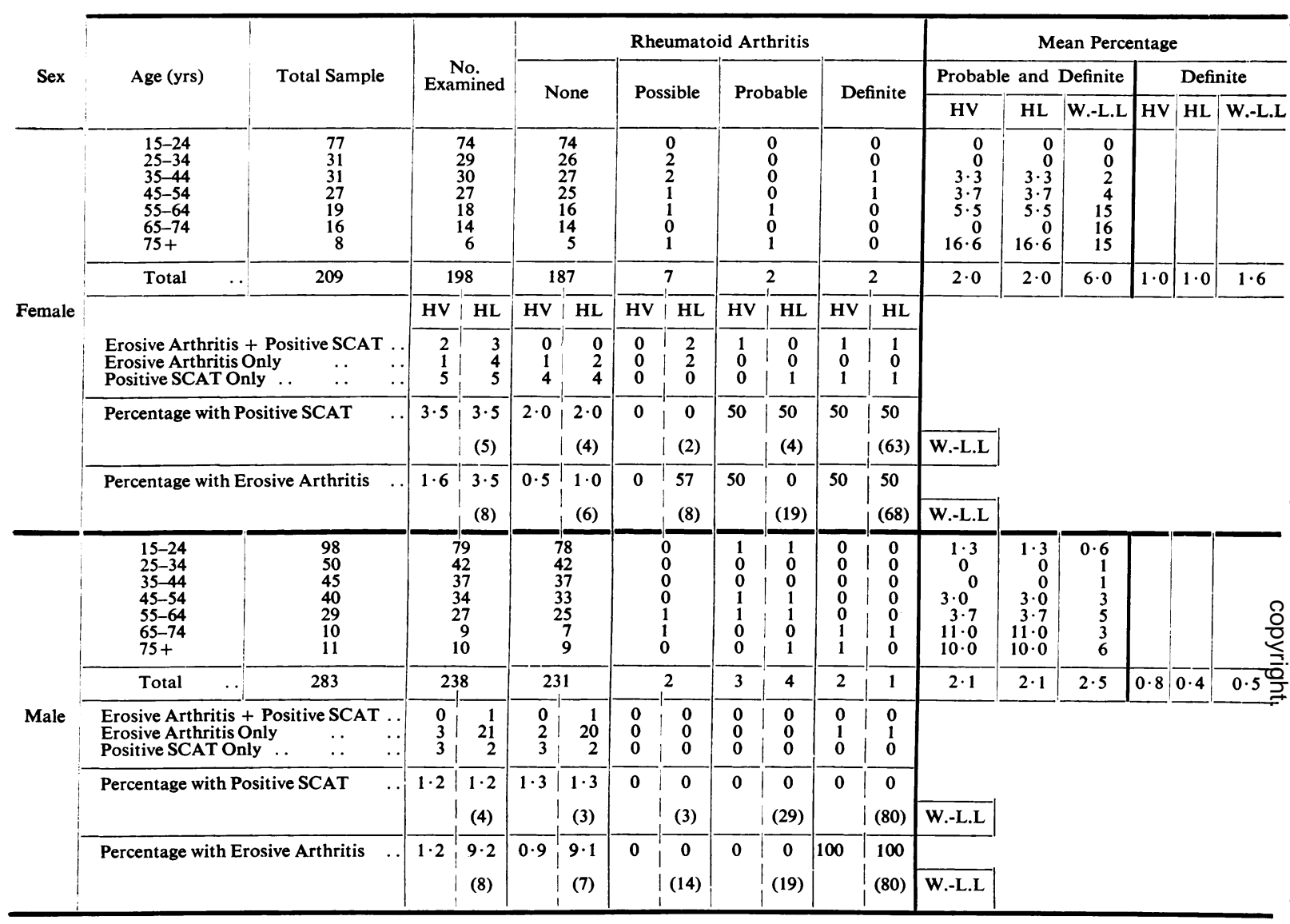

(B) 1962 Criteria-(Kellgren, 1962). Tables II and III (overleaf).

(1) Clinical.-Diagnostic criteria for inactive disease have been added to the 1958 criteria. The data are evaluated according to a gradient of disease, as recommended.

(2) Serological.-The SCAT is used in assessing the gradient of disease. Results of other serological tests are given.

(3) Radiological.-Both Vancouver and Lawrence interpretations of $x$ rays are used. (Lawrence's interpretations are applied to each case individually). Our interpretations are manifestly less sensitive than those of Lawrence.

Note that the findings in ten cases of Marie-Strümpell spondylitis are excluded although these respondents are included in the population totals.

\section{Ancillary Studies}

Uric acid levels were determined on the sera of all respondents by Dr. D. K. Ford. There was no significant difference in mean levels when compared to existing data on Caucasian populations. These data are to be published elsewhere by Ford (1964) as part of a wider population study of serum uric acid levels.

Extensive blood grouping studies were carried out and are to be reported elsewhere (Thomas, 1964). The incidence of the " $r$ " (cde) gene $(0 \cdot 13)$ and of the Lea gene $(0 \cdot 128)$ indicates a significant admixture of Caucasian genes (Lewis, Hildes, Kaita, and Chown, 1961). 
CLASSIFICATION BY 1962 ACTIVE CRITERIA FOR POPULATION STUDIES, BY AGE AND SEX, SHOWING GRADIENT OF R.A.

\begin{tabular}{|c|c|c|c|c|c|c|c|c|c|c|c|c|c|c|c|c|c|c|c|c|c|}
\hline \multirow{4}{*}{ Sex } & \multirow{4}{*}{$\begin{array}{c}\text { Age } \\
\text { (yrs) }\end{array}$} & \multirow{4}{*}{ Total } & & \multicolumn{18}{|c|}{ No. of Active Criteria } \\
\hline & & & Resp. & \multirow{2}{*}{\multicolumn{2}{|c|}{0}} & \multirow{2}{*}{\multicolumn{2}{|c|}{1}} & \multirow{2}{*}{\multicolumn{2}{|c|}{2}} & \multicolumn{4}{|c|}{ Probable R.A. } & \multicolumn{4}{|c|}{ Definite R.A. } & \multicolumn{4}{|c|}{ Classical R.A. } \\
\hline & & & & & & & & & & \multicolumn{2}{|c|}{3} & \multicolumn{2}{|c|}{4} & \multicolumn{2}{|c|}{5} & \multicolumn{2}{|c|}{6} & \multicolumn{2}{|c|}{7} & \multicolumn{2}{|c|}{8} \\
\hline & & & & HV & HL & HV & HL & HV & HL & HV & HL & HV & HL & HV & HL & HV & HL & HV & HL & HV & HL \\
\hline \multirow{8}{*}{ Female } & $15-24$ & 77 & 74 & 72 & 72 & 2 & 2 & & & & & & & 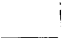 & & & & & & & \\
\hline & $25-34$ & 31 & 29 & 25 & 26 & 2 & 1 & 2 & 2 & & & & & & & & & & & & \\
\hline & $35-44$ & 31 & 30 & 23 & 23 & 4 & 3 & 2 & 3 & & & & & & & & & 1 & 1 & & \\
\hline & $45-54$ & 27 & 27 & 22 & 21 & 3 & 3 & 1 & 2 & & & & & 1 & 1 & & & & & & \\
\hline & $55-64$ & 19 & 18 & 11 & 10 & 5 & 5 & 1 & 2 & & & 1 & 1 & & & & & & & & \\
\hline & $65-74$ & 16 & 14 & 11 & 12 & 3 & 2 & & & & & & & & & & & & & & \\
\hline & $75+$ & 8 & 6 & 3 & 3 & 1 & 1 & 1 & 1 & 1 & 1 & & & & & & & & & & \\
\hline & Total & 209 & 198 & 167 & 167 & 20 & 17 & 7 & 10 & 1 & 1 & 1 & 1 & 1 & 1 & 0 & 0 & 1 & 1 & 0 & 0 \\
\hline \multirow{8}{*}{ Male } & $15-24$ & 98 & 79 & 77 & 76 & 1 & 2 & & & & & 1 & 1 & & & & & & & & \\
\hline & $25-34$ & 50 & 42 & 38 & 31 & 3 & 10 & & & & & & & & & & & & & & \\
\hline & $35-44$ & 45 & 37 & 35 & 33 & 2 & 4 & & & & & & & & & & & & & & \\
\hline & 45-54 & 40 & 34 & 29 & 28 & 2 & 4 & 1 & 1 & & & 1 & 1 & & & & & & & & \\
\hline & 55-64 & 29 & 27 & 26 & 24 & 1 & 3 & & & 1 & 1 & & & & & & & & & & \\
\hline & $65-74$ & 10 & 9 & 9 & 8 & & 1 & & & & & & & & & & & & & & \\
\hline & $75+$ & 11 & 10 & 8 & 7 & 2 & 3 & & & & & & & 1 & & & & & & & \\
\hline & Total & 283 & 238 & 222 & 207 & 11 & 27 & 1 & 1 & 1 & 1 & 2 & 2 & 1 & 0 & 0 & 0 & 0 & 0 & 0 & 0 \\
\hline
\end{tabular}

$\mathrm{HV}=$ Vancouver $x$-ray Interpretation.

$\mathrm{HL}=$ Lawrence $x$-ray Interpretation.

Note: All data on cervical spines excluded. Ten males with Marie-Strümpell spondylitis excluded.

\section{Discussion}

From the comparative study presented it seems clear that there is no important difference between the point prevalence of rheumatoid arthritis in the Haidas and in the people of Northern England. Although these populations differ considerably in age distribution, the Haidas being generally younger, there was no outstanding difference in prevalence. As in other populations, female Haidas show evidence of two or three times as much disease as males.

In the Haida females there was less "probable" rheumatoid arthritis than in the W.-L. females.

In the films of Haida males, Lawrence found a high frequency of erosive disease (of minimal degree). When this is correlated with other data (Table II), it is seen that most of these are isolated findings in otherwise normal respondents (with the exception of six cases of Marie-Strümpell spondylitis). We passed these films as normal or doubtful and arrived at a much lower prevalence of erosive disease in Haida males.
The Haidas and the English respondents spring from widely different racial sources; Caucasian genes have been introduced into the Haidas in recent generations. Not only do diet, mode of life, and climatic environment differ greatly in these two peoples, but the physical and psychological stresses faced by them must differ in kind and degree. The diffuse distribution of rheumatoid arthritis throughout areas of the world so far studied testifies to its ubiquity and makes one pessimistic about the possibility that its occurrence can be related to environmental factors or racial heredity.

These findings are in sharp contrast to what we know of Marie-Strümpell spondylitis, which appears to be unusually prevalent in the Haidas. Accurate definition of the distribution of this disease assumes great importance, for a difference in prevalence of the order suggested by the Haida study may contain a key to the aetiology.

Comments on Criteria.-To compare disease prevalence in two populations, it would be desirable to 
TABLE III

CLASSIFICATION BY 1962 INACTIVE CRITERIA FOR POPULATION STUDIES BY AGE AND SEX, SHOWING GRADIENT OF R.A.

\begin{tabular}{|c|c|c|c|c|c|c|c|c|c|c|c|c|c|}
\hline \multirow{4}{*}{ Sex } & \multirow{4}{*}{ Age (yrs) } & \multirow{4}{*}{ Total } & \multirow{4}{*}{ Resp. } & \multicolumn{10}{|c|}{ Number of Inactive Criteria } \\
\hline & & & & \multirow{2}{*}{\multicolumn{2}{|c|}{$\mathbf{0}$}} & \multirow{2}{*}{\multicolumn{2}{|c|}{1}} & \multirow{2}{*}{\multicolumn{2}{|c|}{$\frac{\text { Probable R.A. }}{2}$}} & \multicolumn{4}{|c|}{ Definite R.A. } \\
\hline & & & & & & & & & & \multicolumn{2}{|c|}{3} & \multicolumn{2}{|c|}{4} \\
\hline & & & & HV & HL & HV & HL & HV & HL & HV & HL & HV & HL \\
\hline \multirow{8}{*}{ Female } & $15-24$ & 77 & 74 & 73 & 73 & 1 & 1 & & & & & & \\
\hline & $25-34$ & 31 & 29 & 26 & 26 & 3 & 3 & & & & & & \\
\hline & $35-44$ & 31 & 30 & 25 & 23 & $* * 5$ & 7 & & & & & & \\
\hline & $45-54$ & 27 & 27 & 21 & 21 & 5 & 5 & & & & & $* * 1$ & 1 \\
\hline & $55-64$ & 19 & 18 & 11 & 10 & $* 7$ & 7 & & 1 & & & & \\
\hline & $65-74$ & 16 & 14 & 11 & 11 & 2 & 1 & 1 & 2 & & & & \\
\hline & $75+$ & 8 & 6 & 1 & 2 & 4 & 3 & & & & & $* 1$ & 1 \\
\hline & Total & 209 & 198 & 168 & 166 & 27 & 27 & 1 & 3 & 0 & 0 & 2 & 2 \\
\hline \multirow{8}{*}{ Male } & $15-24$ & 98 & 79 & 76 & 75 & $* 3$ & 4 & & & & & & \\
\hline & $25-34$ & 50 & 42 & 39 & 33 & 3 & 9 & & & & & & \\
\hline & $35-44$ & 45 & 37 & 31 & 29 & 6 & 8 & & & & & & \\
\hline & $45-54$ & 40 & 34 & 28 & 26 & $* 6$ & 8 & & & & & & \\
\hline & $55-64$ & 29 & 27 & 23 & 23 & $* 3$ & 3 & 1 & 1 & & & & \\
\hline & $65-74$ & 10 & 9 & 8 & 7 & 1 & 1 & & & & 1 & & \\
\hline & $75+$ & 11 & 10 & $* * 9$ & 7 & 1 & 3 & & & & & & \\
\hline & Total & 283 & 238 & 214 & 200 & 23 & 36 & 1 & 1 & 0 & 1 & 0 & 0 \\
\hline
\end{tabular}

use the same observer to gather and evaluate all data. It is well known that there is often considerable difference among observers in interpretations of $x$ rays (Kellgren and Lawrence, 1957). Standardization of serological tests for different methods and laboratories is also different (Bozsóky, 1963). An examination of our data shows the expected disparities in these observations. It was somewhat surprising, however, to find that the substitution of a different serological test or a different set of $x$-ray interpretations did not alter the final prevalence figures to any important degree. It is clear that the weight of evidence for the A.R.A. definition of disease lies with the clinical criteria and that wide differences in serological or radiological data can be absorbed without disturbing the found prevalences. Moreover, in the Haida study, most of the additional positive findings, from the more sensitive tests or observers, were scattered among the general population. This increased the numbers of cases with single or double criteria but did not, with any frequency, add the extra positive criteria necessary to change cases from possible to probable, or from probable to definite (Table IV). The present definition of disease by the A.R.A. criteria tolerates differences in observations of this kind, and comparisons between different studies are not compromised.

TABLE IV

SUMMARY OF DISEASE PREVALENCE 1962 AND 1958 CRITERIA COMPARED, BY SEX

\begin{tabular}{|c|c|c|c|c|c|c|}
\hline \multirow{3}{*}{ Sex } & \multirow{3}{*}{ Disease } & & \multicolumn{4}{|c|}{ Mean Prevalence per cent. } \\
\hline & & & \multicolumn{2}{|c|}{1962} & \multicolumn{2}{|c|}{1958} \\
\hline & & & $H V$ & $H L$ & $H V$ & $H L$ \\
\hline Female & $\begin{array}{l}\text { Definite } \\
\text { Probable }\end{array}$ & $\begin{array}{l}\cdots \\
\cdots\end{array}$ & $\begin{array}{l}1 \cdot 5 \\
0 \cdot 5\end{array}$ & $\begin{array}{l}1 \cdot 5 \\
0 \cdot 5\end{array}$ & $\begin{array}{l}1 \cdot 0 \\
1 \cdot 0\end{array}$ & $\begin{array}{l}1 \cdot 0 \\
1 \cdot 0\end{array}$ \\
\hline Male & $\begin{array}{l}\text { Definite } \\
\text { Probable }\end{array}$ & $\begin{array}{l}\ldots \\
\cdots\end{array}$ & $\begin{array}{l}0 \cdot 4 \\
1 \cdot 3\end{array}$ & $\begin{array}{l}0 \cdot 4 \\
1 \cdot 7\end{array}$ & $\begin{array}{l}0 \cdot 8 \\
1 \cdot 3\end{array}$ & $\begin{array}{l}0 \cdot 4 \\
1 \cdot 7\end{array}$ \\
\hline
\end{tabular}

1962 Criteria: Lawrence's more sensitive $x$-ray interpretations produce an increase in the frequency of respondents fulfilling one or two criteria, but no important difference in disease prevalence.

1958 v. 1962 Criteria: A slight increase is found in definite disease in females by the new criteria. 
It is, however, disquieting to a rheumatologist to find that a somewhat non-specific criterion such as morning stiffness throws as much weight into the scales as would a Grade 3 or Grade $4 x$-ray finding. Most would feel that the $x$-ray abnormality is all but diagnostic. This situation is somewhat rectified in the A.R.A. 1962 criteria by the addition of an "inactive category", where radiological and serological findings have relatively greater impact.

The expression of positive findings as a "gradient" of disease may prove to be the most informative method of presenting this kind of data (Table V). Examination of Tables II and III shows that positive criteria are found in a discontinuous gradation rather than in a smooth distribution. The few cases of definite disease seem not to be threatened by less sensitive observations; nor are there many individuals with four positive criteria which could be increased to a definite category by more "sensitive" observations.

TABLE V

GRADIENT OF DISEASE BY 1962 A.R.A. CRITERIA (HV) 436 RESPONDENTS-FEMALES AND MALES

\begin{tabular}{|c|c|c|c|}
\hline \multirow{2}{*}{\multicolumn{2}{|c|}{ No. of Criteria }} & \multicolumn{2}{|c|}{ Subjects } \\
\hline & & \multirow[b]{2}{*}{$\begin{array}{c}\text { Number } \\
31 \\
8 \\
2 \\
3 \\
2 \\
0 \\
1\end{array}$} & \multirow{2}{*}{$\begin{array}{c}\text { Percentage } \\
7 \cdot 1 \\
1 \cdot 8 \\
0.46 \\
0.7 \\
0.46 \\
0 \\
0.23\end{array}$} \\
\hline Active & $\begin{array}{l}1 \\
2 \\
3 \\
4 \\
5 \\
6 \\
7\end{array}$ & & \\
\hline Inactive & $\begin{array}{l}1 \\
2 \\
3 \\
4\end{array}$ & $\begin{array}{r}50 \\
2 \\
0 \\
2\end{array}$ & $\begin{array}{c}11 \cdot 4 \\
0 \cdot 46 \\
0 \\
0 \cdot 46\end{array}$ \\
\hline
\end{tabular}

frequently experienced joint swellings in association with forgotten or unnoticed trauma. On consideration, however, it was clear that another rheumatologist would necessarily have returned with similar clinical data.

TABLE VI

CORRELATION OF MORNING STIFFNESS WITH OTHER FINDINGS (HV)

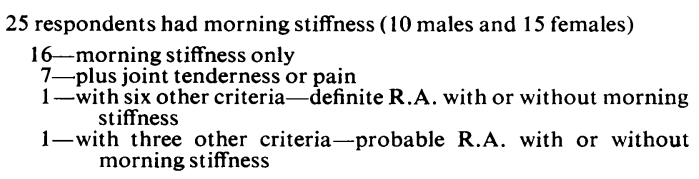
stiffness

1-with three other criteria-probable R.A. with or without morning stiffness

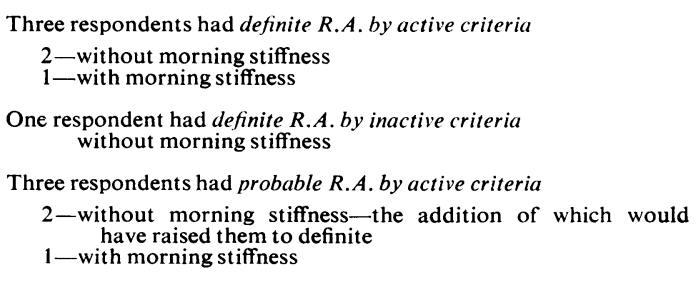

These correlations are given to show our experience with this criterion, one which was difficult to evaluate in the Haidas. Its value may be greater in more sophisticated communities.

Definite features of rheumatoid disease were easily recognizable. Most observers would have excluded uncertain clinical data, as we did in this study. Much of our difficulty concerned the acceptance or rejection of a finding the inclusion of which would only have increased the number of respondents with a low score of one or two criteria.

In re-examining our individual histories, we found that we had had no difficulty with this kind of clinical feature in patients who already had several other positive criteria.

For these reasons we feel that the HL-W.-L.L comparison is not compromised by using Vancouver clinical gradings for the HL assessment.

Comments on Serological Data.-Comparison of the several serological tests used in this study shows that they differ considerably in sensitivity, but not in specificity (Table VII, opposite). Had the determining titre for a positive result been raised in the more sensitive tests, no loss of specificity would have resulted. When the results of the tests were applied separately to the scores of the individual Haida respondents, the found prevalence of definite disease was not altered. Probable disease would have been slightly increased (by two) had the latex, Bentonitefixation test, or sensitized human " $O$ " cell test been employed in place of the SCAT. All tests showed 
TABLE VII

RESULTS OF SEROLOGICAL TESTS COMPARED

\begin{tabular}{|c|c|c|c|c|c|c|c|c|}
\hline \multirow[b]{2}{*}{ Age (yrs) } & \multirow[b]{2}{*}{ Sex } & \multirow[b]{2}{*}{ Code } & \multirow[b]{2}{*}{$\begin{array}{c}\text { Per cent. } \\
\text { Total Tested }\end{array}$} & \multicolumn{4}{|c|}{ Results of Serological Tests } & \multirow[b]{2}{*}{$\begin{array}{l}\text { No. A.R.A. Active Criteria (1962) } \\
\text { excluding Serological }\end{array}$} \\
\hline & & & & $\underset{\substack{\text { BFT } \\
(1 / 32)}}{\text { Bunim) }}$ & $\begin{array}{c}\text { SHC } \\
\text { (Ford) } \\
(1 / 16)\end{array}$ & $\begin{array}{l}\text { Latex } \\
\text { (Ford) } \\
(1 / 160)\end{array}$ & $\begin{array}{l}\text { SCAT } \\
\text { (Baill) } \\
(1 / 32)\end{array}$ & \\
\hline $\begin{array}{l}39 \\
16 \\
22 \\
17 \\
49 \\
33 \\
30 \\
78 \\
32 \\
76\end{array}$ & $\begin{array}{l}\mathbf{M} \\
\mathbf{M} \\
\mathbf{M} \\
\mathbf{M} \\
\mathbf{M} \\
\mathbf{M} \\
\mathbf{M} \\
\mathbf{F} \\
\mathbf{F} \\
\mathbf{F}\end{array}$ & $\begin{array}{l}140 \\
151 \\
225 \\
250 \\
279 \\
345 \\
403 \\
432 \\
487 \\
510\end{array}$ & 8 & $\begin{array}{l}32 \\
32 \\
32 \\
32 \\
32 \\
32 \\
32 \\
32 \\
32 \\
32\end{array}$ & $\begin{array}{l}\overline{64} \\
= \\
\overline{1} \\
\overline{16} \\
{ }_{24}\end{array}$ & $\begin{array}{l}= \\
= \\
= \\
\bar{z} \\
\overline{160}\end{array}$ & $\begin{array}{l}= \\
= \\
= \\
= \\
=\end{array}$ & $\begin{array}{l}0 \\
0 \\
0 \\
0 \\
0 \\
0 \\
0 \\
0 \\
0 \\
2\end{array}$ \\
\hline $\begin{array}{l}60 \\
42 \\
20 \\
17 \\
26 \\
50 \\
32 \\
80 \\
41 \\
79\end{array}$ & $\begin{array}{l}\mathbf{M} \\
\mathbf{M} \\
\mathbf{F} \\
\mathbf{M} \\
\mathbf{M} \\
\mathbf{F} \\
\mathbf{M} \\
\mathbf{F} \\
\mathbf{M} \\
\mathbf{M}\end{array}$ & $\begin{array}{r}26 \\
174 \\
192 \\
201 \\
229 \\
256 \\
293 \\
347 \\
360 \\
406\end{array}$ & $5 \cdot 7$ & $\begin{array}{l}64 \\
64 \\
64 \\
64 \\
64 \\
64 \\
64 \\
64 \\
64 \\
64\end{array}$ & $\begin{array}{l}64 \\
64 \\
32 \\
\overline{7} \\
128 \\
16 \\
=\end{array}$ & $\begin{array}{l}2,560 \\
= \\
\overline{160} \\
640 \\
\overline{640} \\
=\end{array}$ & $\begin{array}{l}64 \\
= \\
= \\
= \\
= \\
=\end{array}$ & $\begin{array}{l}2 \\
0 \\
0 \\
0 \\
0 \\
1 \\
0 \\
0 \\
0 \\
0\end{array}$ \\
\hline $\begin{array}{l}29 \\
66 \\
38 \\
42 \\
39\end{array}$ & $\begin{array}{l}\mathbf{F} \\
\mathbf{M} \\
\mathbf{M} \\
\mathbf{F} \\
\mathbf{F}\end{array}$ & $\begin{array}{r}83 \\
298 \\
335 \\
395 \\
493\end{array}$ & $3 \cdot 4$ & $\begin{array}{l}128 \\
128 \\
128 \\
128 \\
128\end{array}$ & $\begin{array}{c}\overline{64} \\
\overline{128} \\
\overline{128}\end{array}$ & $\frac{\overline{\bar{F}}}{\overline{1,280}}$ & $\begin{array}{l}= \\
=\end{array}$ & $\begin{array}{l}0 \\
0 \\
0 \\
0 \\
2\end{array}$ \\
\hline $\begin{array}{l}45 \\
33 \\
52 \\
42 \\
75 \\
62 \\
67 \\
48 \\
66 \\
42\end{array}$ & $\begin{array}{l}\mathbf{F} \\
\mathbf{M} \\
\mathbf{F} \\
\mathbf{F} \\
\mathbf{F} \\
\mathbf{M} \\
\mathbf{F} \\
\mathbf{F} \\
\mathbf{F} \\
\mathbf{M}\end{array}$ & $\begin{array}{c}233 \\
508 \\
191 \\
213 \\
247^{*} \\
271^{* *} \\
382 \\
9 \\
46 \\
159\end{array}$ & $2 \cdot 3$ & $\begin{array}{r}256 \\
256 \\
512 \\
512 \\
512 \\
512 \\
512 \\
1,024 \\
1,024 \\
4,096\end{array}$ & $\begin{array}{r}32 \\
128 \\
256 \\
1,024 \\
512 \\
32 \\
64 \\
256 \\
64\end{array}$ & $\begin{array}{l}2,560 \\
160 \\
5,120 \\
5,120 \\
5,120 \\
2,560 \\
1,280 \\
2,560 \\
2,560 \\
2,560\end{array}$ & $\begin{array}{l}\bar{z} \\
\overline{7} \\
64 \\
64 \\
32 \\
256 \\
64 \\
128 \\
-\end{array}$ & $\begin{array}{l}0 \\
0 \\
0 \\
6 \\
2 \\
0 \mathrm{MSS}^{* *} \\
0 \\
4 \\
0 \\
0\end{array}$ \\
\hline $\begin{array}{l}58 \\
22 \\
20 \\
65 \\
20 \\
53 \\
54 \\
21\end{array}$ & $\begin{array}{l}\mathbf{M} \\
\mathbf{F} \\
\mathbf{F} \\
\mathbf{M} \\
\mathbf{M} \\
\mathbf{F} \\
\mathbf{F} \\
\mathbf{F}\end{array}$ & $\begin{array}{r}15 \\
33 \\
61 \\
105 \\
358 \\
465 \\
476 \\
104\end{array}$ & & $\begin{array}{l}= \\
= \\
= \\
=\end{array}$ & $\begin{array}{r}16 \\
16 \\
16 \\
16 \\
16 \\
16 \\
16 \\
1,024\end{array}$ & $\begin{array}{l}= \\
= \\
= \\
=\end{array}$ & $\begin{array}{l}= \\
\bar{z} \\
\overline{3} \\
64\end{array}$ & $\begin{array}{l}0 \\
1 \\
0 \\
0 \\
0 \\
0 \\
0 \\
0\end{array}$ \\
\hline 43 & M & 492 & & - & - & 160 & - & 0 \\
\hline $\begin{array}{l}75 \\
54 \\
19 \\
59\end{array}$ & $\begin{array}{l}\mathbf{M} \\
\mathbf{M} \\
\mathbf{M} \\
\mathbf{F}\end{array}$ & $\begin{array}{r}45 \\
258 \\
329 \\
489\end{array}$ & & $\bar{z}$ & $\begin{array}{l}z \\
z\end{array}$ & $\bar{z}$ & $\bar{z}$ & $\begin{array}{l}5 \\
4 \\
4 \\
4\end{array}$ \\
\hline
\end{tabular}

* Two active criteria but definite by four inactive criteria.

** Marie-Strümpell Spondylitis.

equal ability to contribute to the definition of definite rheumatoid arthritis without disparity-all were in accord on sera from four definite cases, three positive and one negative by all tests.

The meaning of a positive serological test in people who have no other evidence of rheumatoid arthritis has so far escaped definition in this kind of study. We have no reason to suspect a greater than normal incidence of spirochaetal disease in the Haidas. Tuberculosis is more common in these people than in other Canadians. Some non-rheumatoid Haidas showed good titres in several tests, suggesting the presence of an important serum reactant; others reacted sporadically to one or more tests in no discernible pattern.

As reported previously (Part I), all four tests agreed in one sero-positive and nine sero-negative cases of Marie-Strümpell spondylitis.

The SCAT titres reported in the Leigh and Wensleydale studies are compared with those in the Haida Indians in Table VIII (overleaf).

Comments on Radiological Data.-We found five cervical spine films with an abnormal atlantoodontoid articulation (Jackson, 1950; Ball and Lawrence, 1961 ; Martel, 1961 ; Hinck and Hopkins, 
TABLE VIII

DISTRIBUTION OF SCAT TITRES IN MALE AND FEMALE HAIDA INDIANS, COMPARISON WITH LEIGH AND WENSLEYDALE RESULTS

\begin{tabular}{|c|c|c|c|c|c|c|c|c|c|c|c|c|}
\hline \multirow{2}{*}{\multicolumn{3}{|c|}{ Area of Survey }} & \multirow{3}{*}{$\frac{\begin{array}{c}\text { Total } \\
\text { Sample }\end{array}}{1,614}$} & \multirow{3}{*}{$\begin{array}{l}\begin{array}{c}\text { Total } \\
\text { Tested }\end{array} \\
1,295\end{array}$} & \multicolumn{8}{|c|}{ Titre* } \\
\hline & & & & & $<4$ & 4 & 8 & 16 & 32 & $64-128$ & $256-512$ & $>32$ \\
\hline \multirow{2}{*}{ Leigh } & No. & $\cdots !$ & & & 758 & 237 & 149 & 79 & 38 & 26 & 8 & 72 \\
\hline & Per Cent. & $\cdots$ & & 100 & $58 \cdot 6$ & $18 \cdot 3$ & $11 \cdot 5$ & $6 \cdot 1$ & $2 \cdot 9$ & $2 \cdot 0$ & 0.6 & $5 \cdot 5$ \\
\hline Wensleydale & No. $\quad$. & $\cdots$ & 1,062 & 931 & 770 & 70 & 61 & 9 & 11 & 5 & 5 & 21 \\
\hline \multirow{2}{*}{ Haida } & No. $\quad \ldots$ & $\cdots$ & 492 & 436 & 399 & 20 & 4 & 4 & 3 & 6 & 1 & 10 \\
\hline & Per Cent. & $\cdots$ & & 100 & $91 \cdot 5$ & $4 \cdot 6$ & 0.91 & 0.91 & 0.69 & $1 \cdot 4$ & 0.23 & $2 \cdot 2$ \\
\hline
\end{tabular}

* (Ball, 1961: Table III).

1960). One of these had primarily basilar invagination. One film, a good lateral projection, showed an atlanto-odontoid interval of $5 \mathrm{~mm}$. The remaining three showed an atlanto-odontoid separation of over $3 \mathrm{~mm}$. but were taken in slight obliquity. These films were reviewed with a neurological radiologist (McRae, 1962), who suggested that obliquity of the projection could give rise to a spurious measurement of the atlanto-odontoid interval. None of these five subjects gave a history of infection or injury. None fulfilled any A.R.A. criteria for active or inactive rheumatoid arthritis, or showed any suspicion of rheumatoid disease.

Lawrence found $x$-ray changes of rheumatoid arthritis in ten Haida cervical spine films. We agreed on only two of these. Of the ten considered abnormal by Lawrence, one was a definite case of rheumatoid arthritis by other criteria; in two he found further erosive changes in hands or feet; one gave a history of "polyarthritis" but had no other findings; six were negative by all other criteria.

Had we included either Lawrence's or our own interpretations of cervical spine films, the prevalence of probable or definite disease would have remained unaffected (these criteria failing to add the critical additional one to raise the individual score). Cervical spine films are troublesome to obtain in the field and further consideration might be given to their interpretation and value in epidemiological studies.

The Vancouver observers failed to find evidence of definite erosive disease in the films of hands or feet of the ten cases of Marie-Strümpell spondylitis. Lawrence found evidence of minimal erosive disease in six of the ten.

In our interpretation no film of the feet showed rheumatoid abnormalities in the absence of definable lesions in the hands. We agree that we have difficulty in the interpretation of films of the feet and tend to be conservative in our grading. Lawrence frequently found Grade 2 disease in the feet, occasionally in respondents without evidence of the disease by any other criteria, and sometimes associated with $x$-ray evidence of disease elsewhere. As with serological testing, the price of sensitive $x$-ray interpretation may be a lessened specificity. These differences, as mentioned previously, do not assume critical significance in the scoring and assessment of data for overall disease prevalence by current A.R.A. criteria.

\section{Summary}

A survey of a native Indian population for rheumatoid arthritis disclosed a prevalence of definite disease which does not differ significantly from that found in the combined Wensleydale-Leigh study of Lawrence (1961). This survey was designed for close comparison with the W.-L. study. Clinical evaluation in both studies employed the A.R.A. 1958 criteria; and the SCAT test was done under identical conditions. The Haida data was also evaluated by the current A.R.A. 1962 criteria.

A significant difference was found in radiological interpretation between Lawrence and the Vancouver observers. The problem of this interobserver difference was resolved by applying Lawrence's $x$-ray interpretations directly to the Haida data which was then compared with his W.-L. study.

Marie-Strümpell spondylitis was found to have an unexpectedly high prevalence in this native population. Convincing evidence that these people have more Marie-Strümpell spondylitis than exists in other parts of the world will depend on a better 
definition of the prevalence of this disease in other populations.

A follow-up study is planned to define the prevalence of Marie-Strümpell spondylitis in the Haidas more accurately.

We are greatly indebted to Dr. John Lawrence, of the Arthritis and Rheumatism Council Field Unit, whose cooperation made the comparative study possible; and to Dr. John Ball, whose SCAT results are used in our evaluation of disease. Dr. Donald Anderson gave generous help with the statistical evaluations. We again acknowledge the contributions made by many people, some of whom are mentioned in Part I of this paper. We wish to add a special note of acknowledgment for the invaluable contributions of Miss Vicki Scholes, a member of the survey team. In spite of a disability which was shortly to claim her life, she made herself the administrative core of the project, making its successful prosecution possible.

\section{REFERENCES}

Ball, J. (1950). Lancet, 2, 520.

and Lawrence, J. S. (1961). Ann. rheum. Dis., 20, 235.

Bozsóky, S. (1963). Arthr. and Rheum., 6, 641.

Ford, D. K. (1964). Canad. med. Ass. J., 90, 1295.

Hinck, V. C., and Hopkins, C. E. (1960). Amer. J. Roentgenol., 84, 945.

Jackson, H. (1950). Brit. J. Radiol., 23, 672.

Kellgren, J. H. (1962). Bull. rheum. Dis., 13, No. 3, 291. and Lawrence, J. S. (1957). Ann. rheum. Dis., 16, 485.

Lawrence, J. S. (1961). Ibid., 20, 12, Table I (article starts p. 11).

Lewis, M., Hildes, J. A., Kaita, H., and Chown, B. (1961). Amer.J. phys. Anthropol., 19, 383.

McRae, D. C. (1962). Personal communication.

Martel, W. (1961). Amer.J. Roentgenol., 86, 223.

Robinson, H. S., Gofton, J. P., and Price, G. E. (1963). Ann. rheum. Dis., 22, 232.

Ropes, M. W., Bennett, G. A., Cobb, S., Jacox, R., and Jessar, R. A. (1959). Ibid., 18, 49.

Thomas, J. W. (1964). Amer. J. phys. Anthropol., (in press).

Une étude de la maladie rhumatismale dans une population indienne de Canada. II.

$$
\text { RÉSUMÉ }
$$

Une enquête sur l'arthrite rhumatismale franche dans une population indienne indigène révéla que la fréquence de cette maladie était à peu près la même que celle trouvée par Lawrence (1961) par ses enquêtes à Wensleydale et à Leigh. On avait entrepris cette enquête pour comparer les résultats à ceux de Lawrence, employant, comme lui, les critères de la American Rheumatism Association (A.R.A.) de 1958 pour l'évaluation clinique et en effectuant la réaction de Waaler-Rose en des conditions identiques. On se servit aussi de critères de l'A.R.A. (1962) pour évaluer les données des indiens Haida.

On trouva une différence significative dans l'interprétation radiologique entre Lawrence et les observateurs de Vancouver. Le problème de cette différence interobserver fut résolue par l'application de l'interprétation radiologique de Lawrence directement aux données indiennes et par la comparaison ultérieure avec les données anglaises.

On trouva une fréquence surprenante de la spondylite de Marie-Strümpell dans cette population indigène. Pour être certain que la spondylite de Marie-Strümpell est plus fréquente dans cette population que dans tout autre, il faudrait mieux définir la fréquence de cette maladie ailleurs.

On projète d'autres études pour mieux préciser la fréquence de la spondylite de Marie-Strümpell parmi les Haidas.

\section{Estudio de la enfermedad reumatoide en una} población india en Canada. II.

\section{SUMARIO}

Una investigación de la artritis reumatoide franca en una población india indígena reveló que la frecuencia de esta enfermedad fué aproximadamente igual a la encontrada por Lawrence (1961) en sus investigaciones en Wensleydale y Leigh. La investigación fué emprendida con el propósito de comparar sus resultados con los de Lawrence empleando, como él, para la valoración clínica los criterios de la American Rheumatism Association (A.R.A.) de 1958 y ejecutando la reacción de Waaler-Rose en condiciones idénticas. Se usaron también los criterios de la A.R.A. (1962) para valorar los datos de los Haida indios.

Se encontró una diferencia significativa en la interpretación radiológica entre Lawrence y los observadores de Vancouver. El problema de esta difernecia interobserver fué resuelta por la aplicación de la interpretación radiológica de Lawrence a los datos indios y por la comparación consecutiva con los datos ingleses.

Se encontró una frecuencia inesperada de la espondilitis de Marie-Strümpell en esta población indígena. La certeza de que esta frecuencia es realmente mayor en esta población que en otras depende de la mejor definición de la frecuencia de esta enfermedad en otras poblaciones.

Se anticipa otras investigaciones para definir con más precisión la frecuencia de la espondilitis de MarieStrümpell entre los indios Haida. 